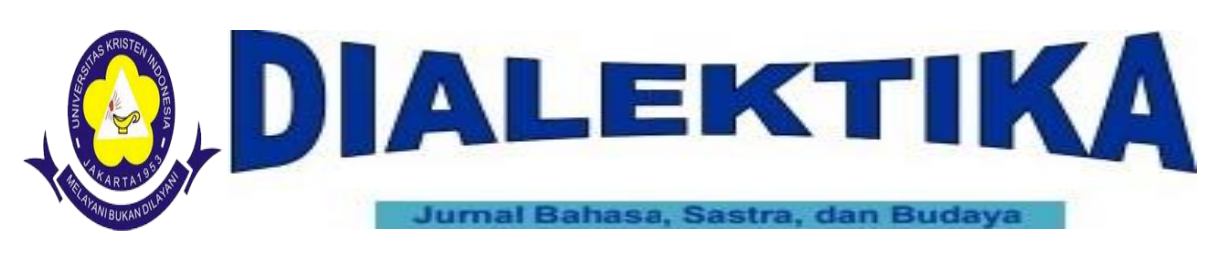

ISSN: 2338-2635

\title{
BAHASA DAN IDENTITAS DALAM STUDENT HIDJO: TINJAUAN SOSIOLOGI SASTRA
}

\author{
Galuh Sakti Bandini \\ SMA Bina Nusantara \\ Galuh.bandini@binus.edu
}

\begin{abstract}
Abstrak
Dunia sastra Indonesia sebelum kemerdekaan cukup unik. Ditinjau dari segi bahasa, ada dua jenis sastra Indonesia yang beredar di Hindia Belanda, yaitu karya sastra yang menggunakan bahasa Melayu Tinggi dan Bahasa Melayu Pasar. Masing-masing bahasa mewakili ideologi tertentu. Tulisan ini membahas penggunaan bahasa dalam Student Hidjo karya Mas Marco Kartodikromo dan kaittannya dengan identitas, ditinjau dari sudut pandang sosiologi sastra. Dari penelitian ini terlihat bahwa penggunaan bahasa Melayu Rendah yang dicampur bahasa Belanda di dalam Student Hidjo tidak hanya menunjukkan identitas tokoh sebagai intelektualis muda, tapi juga sebagai bentuk perlawanan Mas Marco terhadap kolonialisme.
\end{abstract}

Kata Kunci: Student Hidjo, Mas Marco, Bahasa, identitas, sosiologi sastra.

\begin{abstract}
The world of Indonesian literature before independence was unique. In terms of language, there are two types of Indonesian literature circulating in the Dutch East Indies, literary works that use the High Malay and the Pasar/low Malay. Each language represents a certain ideology. This paper discusses the use of language in Mas Marco Kartodikromo's Student Hidjo and its relation to identity from the sociology of literature. From this research, it can be seen that the use of Low Malay mixed with Dutch in Student Hidjo not only shows the identity of the character as a young intellectual but also as a form of Mas Marco's resistance to colonialism.
\end{abstract}

Keyword: Student Hidjo, Mas Marco, language, identity, sociology of literature 


\section{Pendahuluan}

Dunia Sastra Indonesia sebelum kemerdekaan sangat unik. Sebelum kemerdekaan Indonesia, dunia kesusastraan sudah berkembang sedemikan rupa. Ada banyak pendapat mengenai pembabakan atau periodesasi kesusastraan Indonesia. Teeuw (dalam S, 2017) menyatakan bahwa kelahiran sastra Indonesia dimulai sejak munculnya Azab dan Sengsara karya Merari Siregar pada 1920. Akan tetapi, jauh sebelum itu Indonesia (atau Hindia Belanda) sudah memiliki banyak karya sastra.

Mengikuti periodesasi yang dibuat oleh Untung Yuwono (2007), periodesasi kesusastraan dibagi menjadi tiga. Periode pertama adalah kesusastraan Indonesia klasik atau kesusastraan Indonesia lama. Kedua, periode kesusastraan pra-Indonesia modern atau kesusastraan Melayu-Rendah. Terakhir adalah periode kesusastraan Indonesia modern. Kesusastraan Indonesia modern kemudian dibagi lagi menjadi empat periode, yaitu kesusastraan masa Balai Pustaka (angkatan '20), kesusastraan masa Pujangga Baru (angkata '33), kesusastraan masa angkatan '45 dan 1950-an, kesusastraan masa angkatan '66, dan kesusastraan Indonesia kontemporer. Sebenarnya, periodesasi yang dibuat oleh Yuwono merupakan gabungan pendapat umum dari periodesasi sastra Indonesia yang pernah dibuat. Dari periodesasi tersebut, semakin jelas bahwa sebelum terbitnya Azab dan Sengsara, dunia kesusastraan Indonesia sudah cukup berwarna. Tonggak sastra Indonesia tidak dimulai pada 1920.

Akan tetapi, sesungguhnya sastra di Indonesia tidak dapat dibagi dengan ketat dan kaku melalui periodesasi. Pada tahun 1908, pemerintah Belanda mendirikan komisi bacaan untuk mengontrol bacaan bagi para pribumi, yiatu commissie voor de volkslectuur. Komisi ini berkembang dan mencapai masa kejayaannya pada 1918 di bawah kepemimpinan D.A Rinkes dan berganti nama menjadi Kantoor voor de Volkslectuur atau Kantor Bacaan Rakyat. Komisi ini mengharuskan penggunaan bahasa Melayu yang sesuai dengan tata bahasa Melayu van Opphuijzen atau bahasa Melayu Tinggi. Kebijakan ini dibuat untuk menandingi bacaan atau sastra yang menggunakan bahasa Melayu Rendah. Dan mulai saat itu, komisi tersebut lebih dikenal dengan sebutan Balai Pustaka (Jedamski, 2009).

Kesusastraan berbahasa Melayu Tinggi ini memarjinalkan kesusastraan yang menggunakan bahasa Melayu Rendah. Padahal, kesusastraan berbahasa Melayu Rendah seringkali dipakai untuk menyuarakan semangat nasionalisme zaman itu. Bahasa ini juga bahasa yang sering dipakai untuk surat kabar. Bahasa Melayu Rendah adalah bahasa 
pergaulan sehari-hari yang digunakan oleh masyarakat di Hindia Belanda untuk berkomunikasi atau lingua franca. Bahasa ini dimengerti oleh berbagai lapisan kelas yang ada di masyarakat kolonial Hindia Belanda saat itu sehingga dianggap efektif untuk digunakan dalam kesusastraan.

Pada masa kolonial, di Hindia Belanda terjadi persinggungan budaya yang cukup unik. Belanda membawa budayanya ke Hindia Belanda dan mengalami pergesekan dengan budya yang telah ada di Hindia Belanda. Dari segi bahasa, berarti di Hindia Belanda pada saat itu terdapat tiga bahasa dominan, yaitu bahasa Belanda, bahasa Melayu, serta bahasa daerah. Dalam penggunaannya, bahasa-bahasa itu dapat tercampurcampur, sesuai siapa penggunanya. Dengan kata lain, bahasa dapat digunakan untuk mengidentifikasi identitas penggunanya.

Oleh karena itu, menarik melihat penggunaan bahasa di dalam karya sastra berbahasa Melayu Rendah. Bahasa dapat menunjukkan identitas tokohnya ataupun pembuatnya. Dalam tulisan ini penulis akan membahas penggunaan bahasa dalam novel Student Hidjo karya Mas Marco Kartodikromo. Selain menunjukkan identitas, pilihan bahasa yang digunakan Marco mengindikasikan hal lain yang sehubungan dengan ideologinya.

\section{Sosiologi Sastra}

Penelitian ini menggunakan pendekatan sosiologi sastra. Menurut Damono (2020: 5), sosiologi sastra adalah pendekatan terhadap sastra yang mempertimbangkan segi-segi kemasyarakatan. Pendekatan ini digunakan karena karya sastra tidak dapat dilepaskan dari keadaan sosial yang melingkupinya.

Menurut Swingewood (1972), ada tiga sudut pandang dalam sosiologi sastra. Sudut pandang pertama melihat karya sastra sebagai cerminan zaman tertentu. Sudut pandang kedua melihat peran pengarang dalam memengaruhi sudut pandang yang digunakan di dalam karya. Sementara itu, sudut pandang ketiga melacak bagaimana masyarakat tertentu dalam kurun waktu historis tertentu memaknai sebuah karya sastra.

Damono (2020) menyatakan bahwa kritikus harus berhati-hati dalam menafsirkan "sastra adalah cermin masyarakat". Karya sastra tentu tidak benar-benar menampilkan kenyataan secara utuh apa adanya. Ada peran pengarang yang memilih kenyataan macam apa yang dihadirkan di dalam karya. Dengan demikian karya sastra mencerminkan 
masalah masyarakat secara umum ditilik dari sudut lingkungan tertentu yang terbatas, yang berperan sebagai mikrokosmos sosial. Swingewood (1972) menegaskan bahwa sastra harus dipandang sebagai sistem makna yang berlapis-lapis dan terhubung dengan faktor eksternal. Akan tetapi, bukan berarti keseluruhan karya sastra ditentukan oleh faktor luar tersebut.

Penelitian ini menggabungkan dua pandangan pertama yang dikemukakan oleh Swingewood. Penelitian ini melihat bagaimana keadaan sosial pada suatu masa memengaruhi karya sastra. Selain itu dilihat pula kaitan antara penggunaan bahasa di dalam karya dengan posisi ideologi Mas Marco sebagai pengarang.

\section{Mas Marco Kartodikromo dan Student Hido}

Mas Marco Kartodikromo (selanjutnya Marco) adalah seorang jurnalis sekaligus sastrawan yang aktif sebagai anggota Sarekat Islam Surakarta. Ia dikenal sebagai orang dari kaum pergerakan yang mengusik pemerintah kolonial karena tulisannya. Marco lahir di Cepu pada 25 Maret 1890 dan dikenal dengan sebutan "Singa dari Cepu” (Sumardjo, 2004: 113).

Marco pernah bekerja sebagai juru tulis di Dinas Kehutanan pada 1905. Setelah itu, ia pindah ke semarang dan bekerja sebagai juru tulis di Nederland Indische Spoorweg (NIS), sebuah perusahaan kereta api swasta di Hindia Belanda (Shiraishi, 1997). Pekerjaan ini membuat Marco lebih menguasai bahasa Belanda karena ia memiliki guru pribadi seorang Belanda. Sebelumnya, kemampuan bahasa Belandanya hanya terbatas pada kemampuan membaca karena ia hanya menamatkan sekolah di Tweede Klass Inlandsche Scholen di Bojonegoro dan sekolah swasta bumiputra Belanda di Purworejo (Kesumastuti, 2013).

Kariernya sebagai penulis dimulai pada 1911 ketika ia magang untuk surat kabar Medan Prijaji yang diasuh oleh Tirto Adhi Soerjo. Setelah surat kabar itu bangkrut, ia pindah ke surat kabar Sarotomo. Selain itu, ia pernah menjadi redaksi Doenia Bergerak bersama Tjipto Mangoenkoesoemo. Di Semarang, bersama tokoh-tokoh sayap kiri, seperti Semaoen dan Darsono, ia memimpin surat kabar Sinar Djawa, Sinar Hindia, dan Api (Kesumastuti, 2013; Sumardjo, 2014). 
Dalam dunia sastra, Marco pernah menulis novel, puisi, drama, dan cerpen. Novelnya antara lain Mata Gelap (1914), Student Hidjo (1918), Matahariah (1918-1919), dan Rasa Merdika (1924). Kumpulan puisinya berjudul Sair Rempah-Rempah terbit di Semarang pada 1918. Sedangkan dramanya berjudul Kromo Bergerak diterbitkan di surat kabar Sinar Hindia (Sumardjo, 2004: 114).

Student Hidjo bercerita mengenai percintaan Hidjo, R.A Biroe, R.A Woengoe, dan Betje. Hidjo sudah ditunangkan dengan R.A Biroe sebelum ia diperintahkan ayahnya untuk bersekolah di Belanda. Di Belanda, ia menjalin kisah cinta dengan anak induk semangnya, yaitu Betje. Ketika di Belanda, secara tidak sengaja orangtuanya bertemu dengan keluarga R.A Wongoe yang merupakan adik dari sahabat Hidjo. Orangtua Hidjo sangat menyukai Wongoe dan menjodohkan R.A Wongoe dengan Hidjo, sedangkan R.A Biroe dijodohkan dengan Wardojo, sahabat Hidjo dan kakak dari R.A Wongoe. Hidjo diperintahkan ayahnya untuk kembali ke Jawa dan menikahi R.A Wongoe. Oleh karena itu, ia harus mengakhiri hubungannya dengan Betje. Meskipun begitu, cerita ini ditutup dengan akhir yang damai dan bahagia untuk semua tokohnya. Cerita ini sempat diterbitkan sebagai cerita bersambung dalam surat kabar Sinar Hindia (Sumardjo, 2004).

\section{Bahasa dan identitas dalam Student Hidjo}

Salah satu fungsi bahasa adalah ekspresi, yaitu bahasa digunakan untuk mengekspresikan perasaan, emosi dan keinginan. Bahasa sendiri merupakan tradisi budaya yang dibangun berdasarkan interaksi dari banyak hal (Joseph, 20014). Oleh karena bahasa merupakan tradisi budaya, bahasa dapat digunakan untuk melihat identitas budaya pemakainya.

Identitas secara umum dipahami sebagai ciri-cici atau keadaan khusus seseorang. ${ }^{1}$ Menurut Hall (1996), identitas selalu berubah dan dapat dikonstruksi. Identitas dibangun oleh wacana, untuk itu perlu pemahaman mengenai sejarah dan institusi yang membentuk identitas tersebut melalui pengetahuan yang bersumber dari sejarah, bahasa dan budaya.

Untuk kasus Indonesia sebelum kemerdekaan, kasus bahasanya cukup unik. Sejak masa penjajahan, masyarakat kota di Hindia Belanda merupakan masyarakat yang multikultural. Etnis yang umum diketahui terdapat di perkotaan kolonial adalah Belanda, Indo, Arab, Tionghoa, dan pribumi. Berbagai masyarakat yang terdiri dari berbagai ras

\footnotetext{
${ }^{1}$ Dikutip dari https://kbbi.web.id/identitas
} 
dan etnis memiliki bahasanya masing-masing dan mereka memerlukan satu bahasa lain di luar bahasa mereka untuk saling berkomunikasi. Bahasa yang dipilih untuk berkomunikasi atau lingua franca adalah bahasa Melayu.

Seperti yang disebutkan sebelumnya, bahasa Melayu terbagi menjadi bahasa Melayu Tinggi dan bahasa Melayu Rendah. Bahasa Melayu Tinggi didasarkan pada bahasa Melayu Riau dan berdasarkan tata bahasa Melayu van Ophuijzen. Ragam bahasa Melayu Tinggi digunakan oleh sastra terbitan Balai Pustaka. Selain bahasa Melayu Tinggi, terdapat pula bahasa Melayu Rendah yang merupakan lingua franca dan digunakan sebagai bahasa percakapan sehari-hari. Tetapi pada perkembangannya bahasa ini banyak digunakan oleh pers di Hindia Belanda. Pada abad 20, banyak sastrawan yang berasal dari dunia jurnalistik dan tetap menggunakan bahasa Melayu Rendah untuk karyakaryanya.

Dalam Student Hidjo, Marco tidak menggunakan bahasa Jawa, baik dalam penceritaan maupun dialog yang diucapkan oleh tokohnya yang orang Jawa. Alih-alih menggunakan bahasa Jawa, ia menggunakan bahasa Melayu Rendah dan Belanda. Padahal, latar sosial karya ini adalah masyarakat Jawa tahun 1913. Dengan demikian pemilihan bahasa dalam karya ini dapat menunjukkan identitas Marco yang mewakili kaum jurnalis dan intelektual muda pada masa itu.

Seperti yang sudah dijelaskan sebelumnya, banyak sastrawan yang berasal dari dunia jurnalistik menggunakan bahasa Melayu Rendah. Student Hidjo merupakan cerita bersambung di surat kabar sebelum dijadikan buku, jadi wajar Marco menggunakan bahasa Melayu Rendah. Ia mengikuti tren pada masa itu, mengikuti rekan-rekan sejawatnya yang lain, seperti R.M Tirto Adhi Suryo dan Semaoen.

Akan tetapi, tidak adanya penggunaan bahasa Jawa menunjukkan indikasi tertentu. Saat itu, abad 20, adalah masa awal kebangkitan nasional dan kesadaran akan nasionalisme. Hal itu disebabkan oleh politik etis yang dijalankan oleh pemerintah kolonial. Kunci politik etis adalah edukasi yang direalisasikan dengan pembangunan sekolah secara lebih merata oleh pemerintah kolonial. Tujuan pokok politik etis ini adalah memberantas buta huruf agar dapat meningkatkan kesejahteraan bangsa pribumi. Hasil dari politik etis ini adalah munculnya 'kaum muda' yang berpikiran terbuka dan mampu berbahasa Belanda karena diajarkan di sekolahan-sekolahan, dan inilah awal dari gerbang kesadaran nasional. 
Menurut Shiraishi (1997), kaum muda adalah mereka yang telah memiliki akses dengan dunia barat (dalam hal ini berkaitan dengan Belanda) karena telah mengerti bahasa Belanda. Hal senada juga diungkapkan oleh Alisjahbana (1991) yang menyatakan bahasa Belanda memiliki kedudukan penting dalam masyarakat karena menjadi syarat untuk mendapatkan pendidikan dan pekerjaan yang baik di pemerintahan. Bahasa Belanda menjadi ciri lapisan atas di masyarakat Hindia pada masa itu. Dalam Student Hidjo, penggambaran kaum muda modern ditunjukkan lewat penggunaan bahasa Belanda yang sepenggal-sepenggal ketika bercakap. Hal itu juga dilihat sebagai bukti intelektualitas.

"Tapi cepat, sebab kita sudah siap akan pulang bersamasama dengan famili Hidjo...Apa? ...Verjaardag ${ }^{2}$-nya Papa?...O, ya?...Kebetulan kalau begitu...jadi seperti memberi kehormatan kepada famili Hidjo...kapan ada pesta?...Hari minggu?...Cepat Mas! Dus kom jij ons afhalen ${ }^{3}$ ?...tot straks ${ }^{4}$ !" (Kartodikromo, 2015: 53)

Kutipan di atas diucapkan oleh R.A Woengoe yang menelpon kakaknya, R.M Wardojo. Dapat terlihat dalam kutipan tersebut bahwa Woengoe menggunakan kata, bahkan kalimat, berbahasa Belanda tetapi masih menggunakan bahasa Melayu dan panggilan yang lekat dengan budaya Jawa, yaitu 'Mas'. Hal itu menunjukkan bahwa kaum muda tidak sepenuhnya meninggalkan nilai-nilai tradisional, tetapi sekaligus menunjukkan nilai-nilai modern ala Barat sebagai bentuk peleburan Timur dan Barat.

Selain itu, penggunaan bahasa Belanda menunjukkan statusnya sebagai golongan elite yang mendapat pendidikan bahasa Belanda sehingga mampu menggunakannya. Kedudukan seseorang dapat terlihat dari bahasa yang dipakainya. Orang-orang yang menggunakan bahasa elite, yaitu bahasa Belanda, akan dianggap sebagai orang terhormat. Golongan elite adalah golongan terkecil tetapi memegang peran terpenting untuk seluruh golongan. Orang-orang yang termasuk ke dalam golongan ini adalah golongan Belanda, Indo-Belanda, pihak swasta asing, dan beberapa golongan pribumi Indonesia, Cina, atau Arab (Sumardjo, 2004: 254).

\footnotetext{
2 Ulang tahun

3 Jadi, kamu nanti menjemput, ya?

${ }^{4}$ Sampai nanti
} 
Selain penggunaan bahasa Belanda oleh kaum muda Jawa, Marco memunculkan sesuatu yang cukup menarik. Ia menggambarkan seorang Controleur Belanda bernama Walter yang fasih menggunakan bahasa Jawa. Penggunaan bahasa Jawa Walter juga diiringi oleh ketertarikannya atas budaya Jawa. Ia memuji budaya Jawa dan masyarakat Hindia Belanda.

“Boten wonten napa-napa Romo5!” jawab Contoleur kepada Regent dengan bahasa Jawa.

Perkataan Controleur dengan bahasa Jawa itu bisa membuat semua orang yang mendengar tertawa. (Kartodikromo, 2015: 65)

Penggunaan bahasa Jawa oleh sang Controleur tentu saja merupakan kontras yang sangat terlihat dalam karya ini. Anak muda, yang memang berasal dari Jawa, tidak pernah digambarkan sekalipun menggunakan bahasa Jawa, tetapi Walter, yang berkebangsaan Belanda, malah dibuat fasih berbahasa Jawa. Terlebih, ia menggunakan bahasa Jawa halus untuk berbicara kepada orang yang lebih tua dan hal itu jarang sekali dilakukan oleh seorang Belanda ke pribumi di masa itu. Tentu saja pengarang memiliki maksud tersendiri ketika membuat kontras ini.

Marco sebagai pengarang jelas sekali ingin mengkritik pemerintah kolonial yang sangat merendahkan masyarakat Jawa atau pribumi. Oleh karena itu, dalam karyanya ia menampilkan seorang Belanda yang sangat mahir berbahasa Jawa dan sangat memahami buda Jawa, tetapi pada akhirnya sang Belanda tidak diterima oleh masyarakat Jawa. Hal itu dibuktikan dengan tidak tertariknya R.A Woengoe kepada Walter, meskipun Walter sudah sangat berusaha menarik perhatian Woengoe menggunakan bahasa Jawa. Menurut Hank Maier (2004: 174) dalam Student Hidjo s pesan Marco sangat jelas, yaitu "Belanda dapat dijadikan teman dekat, tetapi tidak dapat dijadikan kerabat. Tetap ada jarak yang memisahkan antara Jawa dan Belanda."

Penggunaan bahasa Belanda yang fasih oleh tokoh-tokohnya yang berasal dari Jawa juga dapat dilihat sebagai upaya pengarang untuk menaikkan derajat bangsa Jawa. Kaum muda jawa direpresentasikan sebagai orang yang maju dengan penggunaan bahasa

\footnotetext{
${ }^{5}$ Tidak ada apa-apa, Bapak!
} 
Belanda atau orang 'Jawa Baru'-sesuai dengan istilah yang dipakai oleh Maier. Hal ini selaras dengan ideologi yang dianut oleh Marco sebagai penulis.

Sebagai jurnalis, Marco aktif di surat kabar-surat kabar progresif yang memberikan gagasan kritis antikolonialisme kepada masyarakat. Seperti yang sudah beberapa kali disebutkan, Student Hidjo sebelum dijadikan buku diterbitkan di dalam surat kabar. Surat kabar memiliki dampak yang luas bagi masyarakat karena dapat menjadi corong untuk menyuarakan gagasan. Student Hidjo yang terbit di surat kabar ingin mengajak pembacanya melawan kolonialisme Belanda dengan menekankan persamaan hak antara kaum pribumi dan Belanda. Oleh karena itu, Student Hidjo juga dimaksudkan untuk mengajak masyarakat melawan kolonialisme. Perlawanan terhadap kolonialisme salah satunya ditunjukkan dengan pemilihan penggunaan bahasa oleh tokoh-tokohnya. Oleh karena itu, novel ini digolongkan sebagai bacaan liar oleh pemerintah kolonial. Bacaan liar menurut Ajip Rosidi (dalam Kesumastuti, 2014) adalah bacaan yang sifat-sifat dan isi karangannya banyak menghasut pikiran rakyat untuk memberontak. Selain itu, persoalan bahasa Melayu Rendah dan isi yang dianggap porno juga merupakan ciri bacaan liar.

\section{Kesimpulan}

Student Hidjo merupakan salah satu bacaan liar karena isinya merupakan ajakan untuk melawan kolonialisme Belanda. salah satu cara melawan kolonialisme di dalam karya itu adalah dengan penggunaan bahasa tokoh-tokohnya. Tokoh pemuda Jawa digambarkan fasih berbahasa Belanda dan sama sekali tidak pernah menggunakan bahasa Jawa. Sebaliknya, seorang tokoh Belanda digambarkan sangat mahir menggunakan bahasa Jawa. Hal tersebut merupakan upaya Marco untuk menggambarkan kaum Jawa Baru.

Penggunaan bahasa Belanda dapat menunjukkan identitas sang tokoh, yaitu sebagai kaum muda intelek yang berasal dari kalangan ekonomi tinggi atau merupakan golongan elite. Akan tetapi, penggunaan bahasa jawa oleh tokoh Belanda juga dapat dilihat sebagai propaganda untuk menaikkan derajat Jawa di mata Belanda. Jadi, penggunaan bahasa dalam karya ini tidak hanya sekadar menunjukkan identitas pemaikainya, tapi juga menunjukkan maksud lain, yaitu perlawanan terhadap kolonialisme Belanda pada saat itu. 


\section{Daftar Pustaka}

Alisjahbana, Sutan Takdir. 1991. "Sejarah Bahasa Indonesia" dalam Masa Lampau Bahasa Indonesia: Sebuah Bunga Rampai. Yogyakarta: Kanisius.

Damono, Sapardi Djoko. 2020. Sosiologi Sastra. Jakarta: Gramedia Pustaka Utama.

Hall, Stuart. 1996. "Who Needs Identity" dalam Question of Cultural Identity, Stuart Hall and Paul Du Gay (ed.). London: Sage Publication.

Joseph, John E. 2004. Language and Identity: National, Ethnic, Religious. Hampshire: Palgrave Macmillan.

Jedamski, Doris. 2009. "Kebijakan Kolonial di Hindia Belanda" dalam Sadur: Sejarah Terjemahan di Indonesia dan Malaysia. Jakarta: Kepustakaan Populer Gramedia.

Kartodikromo, Mas Marco. 2015. Student Hidjo. Yogyakarta: Narasi.

Kesumastuti, Yosepha Ari Hascaryani. 2014. Rasa Merdika Marco Kartodikromo: Sebuah Tinjauan Sosiologi Sastra. Skripsi. Depok: Universitas Indonesia.

Laurenson, Diana \& Alan Swingewood. 1972. The Sociology of Literature. London: Paladin.

Maier, Hank. 2004. We Are Playing Naratives: A Survey of Malay Writing. Leiden: KITLV Press.

S, Yudiono. K. 2007. Pengantar Sejarah Sastra Indonesia. Jakarta: Grasindo.

Shiraishi, Takashi. 1997. Zaman Bergerak: Radikalisme Rakyat di Jawa 1912-1926. Jakarta: Pustaka Utama Grafitti

Sumardjo, Jakob. 2004. Kesusastraan Melayu Rendah: Masa Awal. Yogyakarta: Galang Press.

Yuwono, Untung. 2007. Gerbang Sastra Indonesia Klasik. Jakarta: Wedatama Widya Sastra. 